\title{
Educational Props Development for Primary School and Early Childhood Education Teachers: Teachers Satisfaction Aspect
}

\section{Iqbal Miftakhul Mujtahid ${ }^{*}$, Mery Berlian², Rian Vebrianto ${ }^{3}$, Musa Thahir $^{4}$}

1,2 Universitas Terbuka, Indonesia

3,4 Universitas Islam Negeri Sultan Syarif Kasim Riau, Indonesia

\author{
A R T I C L E I N F O \\ Article history: \\ 02 January 2021 \\ Received in revised form \\ 05 January 2021 \\ Accepted 25 January \\ 2021 \\ Available online 25 \\ Pebruari 2021 \\ Kata Kunci: \\ Cross Sectional Studies, \\ Guru Sains \\ Keywords: \\ Cross Sectional Studies, \\ Science Teachers
}

\begin{abstract}
A B S T R A K
Dalam rangka menjaga keberlangsungan pendidikan IPA melalui kegiatan praktikum/eksperimen, para guru memiliki beberapa masalah dalam mengembangkan alternatif Alat Peraga Pendidikan IPA sederhana yang penyediaannya lebih mudah dan terjangkau serta pemanfaatannya sederhana karena tidak mudah putus. Penelitian ini bertujuan untuk menganalisis tingkat kepuasan dari Program Pengabdian kepada Masyarakat dilakukan berdasarkan permasalahan yang dihadapi oleh Guru Sekolah Dasar dan Pendidikan Anak Usia Dini. Penelitian ini merupakan cross sectional studies dengan menggunakan survey kepuasan terhadap pendampingan yang telah dilakukan. Subjek penelitian yang terlibat dalam penelitian ini sejumlah 30 orang peserta yang akan di nilai dalam penelitian ini. Hasil penelitian menunjukkan bahwa Program Pengabdian kepada Masyarakat berhasil mengatasi masalah yang dihadapi oleh Guru Sekolah Dasar dan Pendidikan Anak Usia Dini. Hal ini dibuktikan dengan partisipasi guru yang tinggi dalam mengikuti pelatihan dan keberhasilan guru dalam mengembangkan alat peraga pendidikan. Penelitian ini memiliki implikasi yang jelas dalam mengembangan media alternative yang inovatif dalam bidang sains.
\end{abstract}

\section{A B S T R A C T}

To maintain the continuity of science education through practicum/experimental activities, teachers have several problems in developing alternative simple science teaching aids which are easier and more affordable to provide and simple to use because they do not break easily. This study aims to analyze the level of satisfaction of the Community Service Program based on the problems faced by Elementary School and Early Childhood Education Teachers. This research is a cross-sectional study using a satisfaction survey of the assistance that has been carried out. The research subjects involved in this study were 30 participants who would be assessed in this study. The results showed that the Community Service Program succeeded in overcoming the problems faced by Elementary School and Early Childhood Education Teachers. This is evidenced by the high participation of teachers in participating in training and the success of teachers in developing educational teaching aids. This research has clear implications in developing innovative alternative media in the field of science.

\section{Introduction}

In educational system, the implementation of learning process becomes more meaningful if the students perform the activities independently, one of them by performing experiment and practicum. There are four educational pillars stated by UNESCO both for the present and the future, those are: learning to know, learning to do, learning to be, and (4) learning to live together (Juliani \& Widodo, 2019; Laksana Dwi, 2016). These pillars illustrate that learning is not only expected to emphasize the concept or cognitive abilities only, but also to emphasize the unity of cognitive, affective, and psychomotor. This is in line with the essences of Natural Sciences which are Natural Science as process, Natural Science as product and Natural Science as behavior (Fajari et al., 2019). Furthermore, the essence of Science contains three aspects, those are science as product, science as process and science as scientific behavior (Hastuti et al., 2018; Kurniawan et al., 2019; Sardinah et al., 2012; Suryawati \& Osman, 2018). These things are really food to be done on the level of Primary School and Early Childhood Education, so students will learn science from the beginning and improve their interest and motivation in learning science (Natural Science). 
According to the Regulation of Minister of Education No. 22 of 2006, the Standard Contents of Natural Science for Primary School/MI are related to find out about Nature systematically, so that Natural Science is not only about mastering the collection of insight in the forms of facts, concepts, or principles, but also a discovery process (Tias, 2017; F. E. Wulandari, 2016). Natural Science Education is expected to be students' media in learning their own selves and surrounding nature as well as further development prospect in its application in daily life. Natural Science is directed for inquiry and action so that it can help the students to understand about surrounding nature deeply (Minawati et al., 2014; Muchindasari, 2016; Yuliyanti, 2016). Learning process emphasizes on giving direct experience in developing competence so that students can explore and understand surrounding natural scientifically. In fact, teachers have several problems in developing alternatives to simple Educational Props alternative of Natural Sciences needs to be developed whose provision is easier and affordable and utilization is simple because it is not easily broken.

Based on that, implementing practicum in learning activities is the "soul" of Natural Science. Practicum activities cannot be separated from the educational props and materials that will be used. This is because Educational Props (APE) have important role in learning which is to train the students' concentration, teach faster, overcome the problem of time, place and language limitation, awaken the human's emotion, increase students' understanding and memory as well as increase freshness in teaching (Hijriati, 2017). This is also encouraged by the opinion that APE has several functions in learning including: 1) supporting the implementation of the students' learning effectively and interestingly; 2) facilities which can trigger the students' activities to learn about sometime without students' realization and designed for multipurpose; and 3) optimizing the students' development (Astini et al., 2017). Therefore, it can be understood that the use of educatiional props related to daily life problems is integral part of the whole learning process. This defines that APE of Natural Science in learning is a component which is integrated with other components in order to create expected learning situation. Thus, APE of Natural Science is an absolute thing that must present.

Based on the explanation above, it is clear that a teacher must have abilities in developing simple APE of Natural Sciences to imrpove learning objectives achievement expected in the curriculum. However, the problem that might happen in the field is that not all schools/madrasah have educational props, especially laboratory. This becomes the reason of why the teacher cannot perform practicum in Natural Science learning. This is in line with the result of the researcg indicating that: 1) educational props which are not available yet to support the teacher in choosing and using method to deliver the material (Saputri \& Dewi, 2014); 2) problem of using learning props is often ignored due to various reasons (Murdiyanto \& Mahatma, 2014); and 3) the lack of props which support the assistent/lectures in charge (Budiyanto, 2015).

Therefore, APE of Natural Science is an absolute thing that must be exist. Thus, a teacher must have the ability to provide various and creative learning systems, one of them is by making Educational Props (APE) of Natural Science by themselves, simply by utilizing secondhand goods that can be reused to manipulate the original props by not changing the function. Regulation of Minister of National Education Number 16 of 2007 stated that one of the teachers' competences is that teacher must carry out educational learning with the core competences by designing complete learning planning, either for the activities in the classroom, laboratory, and field and use learning media that in accordance with the characteristics of the students. Based on the explanation above, it is clear than teacher must have the ability in making simple APE of Natural Science to improve the learning objectives achievement at school as the expectation of the curriculum. As the school funding is limited, the improvement of teachers' abilities cannot be done yet, so that a workshop needs to be done on the Development of Educational Props of Natural Sciences on Early Childhood Education and Primary School Teachers in order to become Professional teacher in Riau.

\section{Method}

This study is a cross sectional study (Setia M. S. 2016) using a survey of satisfaction with mentoring that has been conducted. The mentoring of service activities was Participatory Action Research (PAR) which was conducted through descriptive approach. The assistance performed in the form of making and development of educational props as such as making props from secondhand goods, environment and kahoot application as interesting and memorable learning media for Primary School and Early Childhood Education teachers in order to become more professional teachers. As many as 30 participants who will be assessed in this study. So, The research involved 30 teachers from SD IT Al Ikhwan Pekanbaru, Riau. The average teachers are female by 22 people $(73.3 \%)$, all are honorary teachers, and GTY/PTY from private schools, have been teaching at school for no more than 5 years by 18 
people (60\%) and most of them have not been certified yet by 28 people $(3.3 \%)$, while those who have been certified were 2 people (6.7\%). Questionnaire was used in this research as the instrument consisting of 30 question items designed into 4 constructs, including material content, material delivery/ explanation, discussion/question and answer and group work practicum. This instrument used 5 scales (Li, 2013) that have been tested regarding its validity and reliability. Based on the calculation, all items were declared valid with $r$-count $>$ r-table so that all question items can be used to measure the training evaluation of the teachers and reliability values $(\alpha)$ are higher than 0.60 for each construct studied which is 0.935 .

The implementation of this program was divided into three stages, those are pre-activities, workshop implementation and post-implementation. The activities/strategies specifically done in each stage were as follow. Pre-activities were done in the form of: 1) improvement of proposal; 2) constructing and printing the guidelines book of the making and use of simple props of Natural Science (Module Procurement) based on the analysis of props need sourced from the analysis of Primary School and Early Childhood teacher materials; and 4) place loan for the socialization and implementation of the program activities for Primary School and Early Childhood Education teachers in Pekanbaru. Implementation Stage includes: 1) the team provides workshop of making simple educational props of Natural Science to 30 Primary School and Early Childhood teacher in Pekanbaru. The workshop was planned through the stages of; 1) designing the props according to the materials wanted to be achieved; 2) demonstration of making APE of Natural Science by the expertise team (three experts); 3) forming small groups in which each group consists of 5-5 peoples; 4) the expertise team provides the workshop of making simple APE of Natural Science; 5) assisting the making of props in each group in which each group will have 1 expects/ research assistant ( 3 people); and 6) providing tutorial by adding the materials of natural science according to the APE that has been designed and other materials considered necessary. Postimplementation (evaluation) conducted through; 1) team conducted evaluation of the program that has been done; 2) team exposed the result of assistance and research to other lecturers; and 3) report of the activities result of Primary School and Early Childhood teachers in Pekanbaru.

After the data were collected from the distribution of questionnaire of evaluating the training of teachers, then the data were analyzed descriptively by using the Statistical Package for Social Sciences (SPSS) version 23.00 for Windows (Bashooir \& Supahar, 2018; Kusumah \& Perdana, 2018; Rizta \& Antari, 2018 ) to see the teachers' response towards the activities of development that has been done either in terms of material contents, delivery of explanation of the material, discussion/ question and answer session, and group work practicum.

\section{Result and Discussion}

\section{Profile of Service Participants}

This research involved 30 teachers of SD IT Al Ikhwan Pekanbaru. Data were analyzed descriptively to obtain the profile of research subject as shown in Table 1.

Table 1. Profile of Service Subjects

\begin{tabular}{llcc}
\hline Research Profile & Categories & N & Percentage (\%) \\
\hline Gender & Male & 8 & 26.7 \\
& Female & 22 & 73.3 \\
Employment Status & GTY/PTY & 15 & 50.0 \\
& Honorary & 15 & 50.0 \\
School Status & Private & 30 & 100.0 \\
Working Period & 5 years & 18 & 60.0 \\
& Between 5 to 10 years & 7 & 23.3 \\
Recent Position & Above 11 years & 5 & 16.7 \\
School & Principal & 1 & 3.3 \\
& Homeroom teachers & 18 & 60.0 \\
Certification Status & Subject Teacher & 11 & 36.7 \\
& Has been certified & 2 & 6.7 \\
\hline
\end{tabular}




\section{Descriptive Analysis}

Analysis of the Impression of Service Program based on Material Contents Construct

Based on the data collected, it was known that the material contents construct of each questionnaire item for the service respondents are presented in Table 2.

Table 2. Impression of Service Program Based on the Material Content Constructs

\begin{tabular}{|c|c|c|c|c|c|}
\hline \multicolumn{2}{|c|}{$\mathbf{N}$} & Minimum & Maximum & Mean & Std. Deviation \\
\hline $\begin{array}{l}\text { Materials are well-organized and } \\
\text { easily understood }\end{array}$ & 30 & 1 & 5 & 3.90 & 1.029 \\
\hline $\begin{array}{l}\text { Materials are relevant and in } \\
\text { accordance to the expectation }\end{array}$ & 30 & 1 & 5 & 3.97 & .890 \\
\hline $\begin{array}{l}\text { Materials are sufficient for me to be } \\
\text { able to make educational props }\end{array}$ & 30 & 1 & 5 & 3.73 & .944 \\
\hline $\begin{array}{l}\text { This materials make me easier to give } \\
\text { understanding to the students to } \\
\text { develop abilities }\end{array}$ & 30 & 1 & 5 & 3.90 & 1.062 \\
\hline Total & 120 & & & 15.5 & \\
\hline Mean & 30 & & & 3.87 & \\
\hline
\end{tabular}

Based on Table 2, it can be obtained that the participants agreed with the material contents presented in the service activities with the average of 3.87 .

\section{Analysis of the Impression of Service Program based on Material Delivery Construct}

Based on the data that has been collected, it was known the materials content for each service questionnaire items for the respondents as presented in Table 3.

Table 3. Impression of Service Program Based on Material Delivery Construct

\begin{tabular}{|c|c|c|c|c|c|}
\hline & $\mathbf{N}$ & Minimum & Maximum & Mean & Std. Deviation \\
\hline $\begin{array}{ll}\text { Presenter understands } & \text { the } \\
\text { materials presented } & \end{array}$ & 30 & 1 & 5 & 4.07 & .828 \\
\hline $\begin{array}{l}\text { Time allocation of the material } \\
\text { delivery is sufficient }\end{array}$ & 30 & 1 & 5 & 3.67 & .884 \\
\hline $\begin{array}{l}\text { The presenter presents the } \\
\text { material content well; easily } \\
\text { understood and implemented }\end{array}$ & 30 & 1 & 5 & 4.07 & .828 \\
\hline Total & 90 & & & 11.8 & \\
\hline Mean & 30 & & & 3.93 & \\
\hline
\end{tabular}

Based on Table 3, it was known that the participants agreed with the material content delivery in the service activities by mean value of 3.93 .

\section{Analysis of the Impression of Service Program Based on Discussion/ Question and Answer Session Construct}

Based on the data that has been collected, it was known the construct of material contents for each questionnaire items for the respondents of the service as presented in Table 4 .

Table 4. Impression of Service Program Based on Discussion/ Question and Answer Session

\begin{tabular}{lccccc}
\hline & $\mathbf{N}$ & Minimum & Maximum & Mean & Std. Deviation \\
\hline $\begin{array}{l}\text { Time allocation for discussion is } \\
\text { sufficient to improve/ encourage my }\end{array}$ & 10 & 5 & 3.97 & 1.033 \\
$\begin{array}{l}\text { understanding } \\
\begin{array}{l}\text { Presenters answer the participants' } \\
\text { question well }\end{array}\end{array}$ & & 1 & 5 & 4.03 & .999
\end{tabular}




\begin{tabular}{lccccc}
\hline & $\mathbf{N}$ & Minimum & Maximum & Mean & Std. Deviation \\
\hline $\begin{array}{l}\text { Overall, the discussion/ question } \\
\text { and answer session is very helpful }\end{array}$ & 30 & 1 & 5 & 4.07 & .944 \\
in improving participants' & & & & \\
understanding & & & & & \\
\hline Total & $\mathbf{9 0}$ & & $\mathbf{1 2 . 1}$ & $\mathbf{4 . 0 3}$ \\
\hline Mean & $\mathbf{3 0}$ & & & \\
\hline
\end{tabular}

Based on Table 4, it was known that the participants agreed on the discussion/ question and answer session in the service program by mean value of 4.03 .

\section{Analysis of Impression of Service Program Based on Group work Practicum Construct}

Based on the data that has been collected, it was known the construct group work practicum for each questionnaire items for the respondents of the service as presented in the following Table 5.

Table 5. Impression of Service Program Based on Group work Practicum Construct

\begin{tabular}{|c|c|c|c|c|c|}
\hline & $\mathbf{N}$ & Minimum & Maximum & Mean & Std. Deviation \\
\hline $\begin{array}{l}\text { Guidelines of Practicum of Making } \\
\text { educational props are provided } \\
\text { well. }\end{array}$ & 30 & 1 & 5 & 3.93 & .944 \\
\hline $\begin{array}{l}\text { Guidelines are constructed well and } \\
\text { easily understood }\end{array}$ & 30 & 1 & 5 & 3.90 & .845 \\
\hline $\begin{array}{l}\text { Facilitators have facilitate the work } \\
\text { well }\end{array}$ & 30 & 1 & 5 & 3.97 & .850 \\
\hline $\begin{array}{l}\text { Time allocation for the practicum } \\
\text { (hand on) is sufficient }\end{array}$ & 30 & 1 & 5 & 3.77 & .858 \\
\hline $\begin{array}{l}\text { Guidelines and time provided as } \\
\text { well as facilitator's assistance can } \\
\text { help the practicum to be } \\
\text { implemented well }\end{array}$ & 30 & 1 & 5 & 4.13 & .900 \\
\hline Total & 150 & & & 19.7 & \\
\hline Mean & 30 & & & 3.93 & \\
\hline
\end{tabular}

Based on Table 5, it can be seen that the participants agreed to group work practicum in the service activities which had mean value of 3.93. Thus, it can be understood that this activity has been well managed and provides new understanding and knowledge and the resource persons presented were mastering the material presented.

\section{Analysis of Interview}

To strengthen the result and discussion of quantitative analysis, qualitative analysis was also performed by coding the interesting themes. Qualitative analysis was done to reflect and carry out followup as the expectation and evaluation of the participants of the service. Based on the results of interview with the participants through Google form, information was obtained that crucial or important activities that needed to be carried out in the future included: presentation of making material video with more detailed applications; making online learning media; making video animation learning and making text that runs when we explain the material; the best learning method used during covid pandemics; how to use instructional media especially in online learning; hands-on practice how to make learning videos; and use of kinemaster application.

The results of the interview also provided information that the obstacles experienced by the participants during the training program included: the implementation time was too short; internet network was not really good; have not been practiced directly using each of their computers; the normalization of time is not maximum; the material presented is lacking in depth; and 6) the material presented by the presenter is only pegged to one subject only. Based on these obstacles, the participants obtained information via Google form to provide suggestions for improvements that need to be done in the future, including: the material presented is further enhanced with the latest and updated ways and ideas; time allocation is more organized; in the future, before starting the workshop, the participants' very important needs are asked first so that time is sufficient; more material for children's creativity; and it should be done for a few days so that more material is received. 


\section{Discussion}

The results showed that the training evaluation results for teachers were categorized as good. This can be seen from the mean value of each construct which is in the good category. The training evaluation was built on four constructs, those are: the contents of the material; delivery/explanation of material; discussion/question and answer session; and group work practicum. In the construct of material content, we obtained information that the material contents were well organized. This is in line with B. Uno's opinion which says that organizing material consists of: Details of material; sequence of material from easy to difficult; and material links to learning objectives (Anwar, 2017; Fitriani, 2019). Furthermore, the process of delivering the material must also fulfill more complete learning content, which involves more than one concept, procedure and principle (Daulae, 2014; Pt.Sudhamantari et al., 2013). Thus, organizing material is a way to sort the material to be delivered logically and regularly, so that clear correlation can be seen between one topic and another during the meeting.

In the construct of material delivery/explanation, we obtained information that the material has been delivered properly. This is because in the delivery process, it has considered understanding the material, time allocation, and ease in understanding the material. These results are in line with research that states that material delivery must consider students, classrooms, methods and the material itself (Handayani, 2011). Furthermore, teachers can plan teaching and learning activities and distribute the time properly and proportionally in the stages of review, overview, explanation of material, exercises, and evaluation of learning (Nursalim, 2011). In addition, the delivery of learning materials which becomes interesting and easily understood by students is one of the factors that can affect the learning outcomes (Nurrita, 2018). Through such a way, the tendency of teachers to give more assignments/exercises to students and only briefly provide material explanations can be avoided.

In the discussion/question and answer session construct, we obtained information that the discussion/question and answer session has been going well. This is due to the time allocation given in the discussion and the responses given by the presenters were in accordance with the expectations of the participants. This result is reinforced by the statement which says that one of the factors for the success of Islamic religious education learning is that teachers provide answers (Ahmad et al., 2017). In addition, feedback or responses to questions are also one of the factors that affect the learning interest and outcomes (Seruni \& Hikmah, 2014). This is in line with research (Febriyanti, 2015) stating that the Trigonometry learning outcomes of students who were given immediate feedback were higher than the Trigonometry learning outcomes of students who were given delayed feedback. In other words, there was an effect of the form of feedback on mathematics learning outcomes. This shows that immediate feedback can increase the learning interest and outcomes.

In the construct of group work practicum, we obtained information that group work practicum are going well. This is because there are guidelines for the practice of making teaching assistance that are neatly arranged, good and interesting. This is in line with the opinion that props as a medium to support practicum and guide teachers in managing IPBA learning (Pujani, 2018). Furthermore, Sudjana said that teaching aids play an important role as tools to create an effective and efficient teaching and learning process (Permata et al., 2019). However, the results of this service are contradictory to the research showing that the lecturer does not provide practical guidance but only a checklist. This is due to the absence of a policy that confirms that all learning in the laboratory must be accompanied by the making of a practicum guide (Sumiatun, 2013).

Research results in this activity also provided that teachers have a strong desire in developing self-competence. This is because the teachers expected that in the future, it is necessary to carry out selfdevelopment activities especially in the making and use of media, videos and online learning methods, especially during the Covid-19 pandemics. This also indicated that teachers have high awareness of the importance of information and technology in the learning process. This awareness is supported by the results of research that states that strategic efforts that must be made in the face of challenges in the era of the industrial revolution include: building awareness, increasing competence, and developing the willingness of teachers to utilize the digital revolution of learning optimally, while simultaneously accommodating and maintaining the essence of education (Cayeni \& Utari, 2019). This opinion is also strengthened by research result claiming that one of the efforts to improve the competence of ICT teachers requires the support of teacher awareness to increase their potential in the field of ICT utilization (Rivalina, 2014). Furthermore, in terms of the implementation of PJJ during Covid-19 pandemics, technology users who have ICT literacy will pay attention to ethics, awareness and responsibility regarding all activities carried out (Latip, 2020). Thus it can be understood that the teacher's awareness is to increase their potential in the field of ICT use and optimize existing resources so that it can become a culture or habit to always improve ICT competencies. 
However, the increased awareness of teachers in improving their potential also still has obstacles, especially the internet network. Even though we understand that the internet network is one source of learning that can be used by students independently (Setiyani, 2010; Tobing, 2019). Therefore, the provision of teacher skills, especially in utilizing internet technology is very necessary. Through the internet, teachers can access various information and knowledge according to the needs relevant to the subject matter, so that the use of the internet as a learning resource, will help simplify and speed up the completion of tasks. In addition to network factors, the obstacle faced is the submission of in-depth material. This is in line with research which says that the focus and attention of educators is more devoted only to the delivery of learning material and learning outcomes. (Hidayat et al., 2020). Furthermore, the delivery of material by the teacher is still less innovative, monotonous and does not involve the full role of students (Y. I. Wulandari et al., 2015) (Yun Ismi Wulandari, Sunarto, and Salman Alfarisy Totalia, 2015).

Based on these results, the process of delivering the material must be presented in depth so that the desired results are achieved optimally. This is supported by research which states that effective learning is not only focused on the results achieved by students, but how effective learning processes can provide good understanding, intelligence, perseverance, opportunity and quality and can provide behavioral change and its application (Fakhrurrazi, 2018). It is also reinforced by Mayer that cognitive theory about multimedia learning representation has the potential to produce learning and deeper understanding than presentations that are presented in only one format (Novitasari, 2016). Thus, it can be understood that in the delivery strategy, the teacher must deliver more than one learning material, one material after another is presented in depth and then sequentially presents the next material in depth as well.

\section{Conclusion}

The reality in the field of a teacher is very limited to be able to improve their skills and abilities in participating in workshops or training, especially in developing educational teaching aids. This mentoring of service involves teachers who are mostly not certified in order to have the ability and skills in the learning process. Based on the results of these activities, the result that they have succeeded in overcoming the problems as evidenced by the high participation of teachers in participating in training and the success of teachers in developing educational teaching aids. This research has clear implications for developing innovative alternative media in the field of science. Another side, it shows that the teachers strongly agree with the service activities as an effort to develop competence, especially in the development and use of educational teaching aids. Based on the results of service and obstacles obtained, the participants gave a number of suggestions including: 1) good cooperation for all educational institutions and systems in the ministry of education so that such positive programs can be implemented well in the future and can be disseminated to all corners or villages in these districts and provinces of Riau; 2) further service needs to be done with more advanced material; and 3) the implementation period can be extended considering the difficulty of transferring skills in a relatively narrow time.

\section{References}

Ahmad, M. Y., Tambak, S., \& Constantiani, N. (2017). Hubungan Metode Tanya Jawab dengan Minat Belajar Peserta Didik pada Mata Pelajaran Pendidikan Agama Islam. Jurnal Pendidikan Agama Islam AlThariqah, 2(1), 89-110. https://doi.org/10.25299/althariqah.2017.vol2(1).650.

Anwar, M. (2017). Menciptakan Pembelajaran Efektif Melalui Hypnoteching. Ekspose, 16(2), $2616-4412$. https://doi.org/10.1017/CB09781107415324.004.

Astini, B. N., Nurhasanah, Rachmayani, I., \& Suarta, I. N. (2017). Identifikasi Pemnafaatan Alat Permainan Edukatif (APE) Dalam Mengembangkan Motorik Halus Anak Usia Dini. Jurnal Pendidikan Anak, 6(1), 31-40. https://doi.org/10.1017/CB09781107415324.004.

Bashooir, K., \& Supahar. (2018). Validitas dan Reliabilitas Instrumen Asesmen Kinerja Literasi Sains Pelajaran Fisika Berbasis STEM. Jurnal Penelitian Dan Evaluasi Pendidikan, 22(2), 168-181. https://doi.org/10.21831/pep.v22i2.20270.

Budiyanto, A. (2015). Pengembangan Alat Peraga Sederhana Struktur dan Organ Dalam Ikan untuk Mempermudah Pembelajaran Pada Praktikum Ikhtiologi Perikanan. Jurnal Kelautan, 8(2), 83-88.

Cayeni, W., \& Utari, A. S. (2019). Penggunaan Teknologi Dalam Pendidikan: Tantangan Guru Pada Era Revolusi Industri 4.0. Prosiding Seminar Nasional Program Pascasarjana, 658-667.

Daulae, T. H. (2014). Menciptakan Pembelajaran yang Efektif. Forum Pedagogik, 6(2), 131-150.

Fajari, L. E. W., Joharman, \& Salimi, M. (2019). Application of Natural Environment Approaches to Improve Science Process Skills in Elementary School Students. SHEs: Conference Series 1, 1(1), 396-402. 
https://doi.org/10.1017/CB09781107415324.004.

Fakhrurrazi. (2018). Hakikat Pembelajaran yang Efektif. At-Tafkir, 11(1), 85-99. https://doi.org/10.32505/at.v11i1.529.

Febriyanti, C. (2015). Pengaruh Bentuk Umpan Balik dan Gaya Kognitif terhadap Hasil Belajara Trigonometri. Formatif: Jurnal Ilmiah Pendidikan MIPA, 3(3), 203-214.

Fitriani, A. (2019). Implementasi Pembelajaran yang Efektif Bagi Siswa Madrasah Ibtidaiyah. AR-RIAYAH : Jurnal Pendidikan Dasar, 3(1), 47-60. https://doi.org/10.29240/jpd.v3i1.624.

Handayani, T. (2011). Membangun Komunikasi Efektif Untuk Meningkatkan Kualitas Dalam Proses Belajar Mengajar. Ta'dib, 16(2), 273-302..

Hastuti, P. W., Nurohman, S., \& Setianingsih, W. (2018). The Development of Science Worksheet Based on Inquiry Science Issues to Improve Critical Thinking and Scientific Attitude. Journal of Physics: Conference Series, 1097(1), 1-7. https://doi.org/10.1088/1742-6596/1097/1/012004.

Hidayat, A., Sa'diyah, M., \& Lisnawati, S. (2020). Metode Pembelajaran Aktif dan Kreatif pada Madrasah Diniyah Takmiliyah di Kota Bogor. Edukasi Islami: Jurnal Pendidikan Islam, 9(1), 161-172.

Hijriati. (2017). Peranan dan Manfaat APE untuk Mendukung Kreativitas Anak Usia Dini. Bunayya : Jurnal Pendidikan Anak, 3(2), 59-69.

Juliani, W. I., \& Widodo, H. (2019). Integrasi Empat Pilar Pendidikan (UNESCO) Melalui Pendidikan Holistik Berbasis Karakter di SMP Muhammadiyah 1 Prambanan. Jurnal Pendidikan Islam, 10(2), 65-74. https://doi.org/10.22236/jpi.v10i2.3678.

Kurniawan, D. A., Astalini, A., Darmaji, D., \& Melsayanti, R. (2019). Students' Attitude towards Natural Sciences. International Journal of Evaluation and Research in Education, 8(3), 455-460. https://doi.org/10.11591/ijere.v8i3.16395.

Kusumah, \& Perdana, E. (2018). Technology Acceptance Model (TAM) of Statistical Package for the Social Sciences (SPSS) Applications. Integrated Journal of Business and Economics, 2(1), 1-11. https://doi.org/10.33019/ijbe.v2i1.47.

Laksana Dwi, S. (2016). Integrasi Empat Pilar Pendidikan (UNESCO) dan Tiga Pilar Pendidikan Islam. AlIdarah: Jurnal Kependidikan Islam, 6(1), 43-61. https://doi.org/10.16309/j.cnki.issn.10071776.2003.03.004.

Latip, A. (2020). Peran Literasi Teknologi Informasi dan Komunikasi Pada Pembelajaran Jarak Jauh di Masa Pandemi Covid-19. EduTeach : Jurnal Edukasi Dan Teknologi Pembelajaran, 1(2), 108-116. https://doi.org/10.37859/eduteach.v1i2.1956.

Li, Q. (2013). A Novel Likert Scale Based on Fuzzy Sets Theory. Expert Systems with Applications, 40(5), 1609-1618. https://doi.org/10.1016/j.eswa.2012.09.015.

Minawati, Z., Haryani, S., \& Pamelasari, S. D. (2014). Pengembangan Lembar Kerja Siswa IPA Terpadu Berbasis Inkuiri Terbimbing Pada Tema Sistem Kahidupan Dalam Tumbuhan Untuk Smp Kelas VIII. In USEJ - Unnes Science Education Journal (Vol. 3, Issue 3, pp. 587-592). https://doi.org/10.15294/usej.v3i3.4265.

Muchindasari, D. (2016). Penerapan Pembelajaran Inkuiri Terbimbing untuk Meningkatkan Keaktifan dan Hasil Belajar IPA Pada Siswa Kelas VIII-B SMPN 4 Madiun. JEMS (Jurnal Edukasi Matematika Dan Sains), 4(1), 19-25. https://doi.org/http://doi.org/10.25273/jems.v4i1.203.

Murdiyanto, T., \& Mahatma, Y. (2014). Pengembangan Alat Peraga Matematika untuk Meningkatkan Minat dan Motivasi Belajar Matematika Siswa Sekolah Dasar. Sarwahita, 11(1), 38-43. https://doi.org/10.21009/sarwahita.111.07.

Novitasari, D. (2016). Pengaruh Penggunaan Multimedia Interaktif Terhadap Kemampuan Pemahaman Konsep Matematis Siswa. FIBONACCI: Jurnal Pendidikan Matematika Dan Matematika, 2(2), 8. https://doi.org/10.24853/fbc.2.2.8-18.

Nurrita, T. (2018). Pengembangan media pembelajaran untuk meningkatkan hasil belajar siswa. MISYKAT: Jurnal Ilmu-Ilmu Al-Quran, Hadist, Syari'ah Dan Tarbiyah, 3(1), 171. https://core.ac.uk/download/pdf/268180802.pdf.

Nursalim. (2011). Diskriminasi Gender di Media Televisi. Marwah: Jurnal Perempuan, Agama Dan Jender, 10(2), 195-203. https://doi.org/10.24014/marwah.v10i2.495.

Permata, A. F., Rezeki, S., \& Amelia, S. (2019). Pengembangan Alat Peraga Kotak Matriks Kelas XI SMK Hasanah Pekanbaru. AKSIOMATIK, 7(2), 63-69.

Pt.Sudhamantari, N., Wiyasa, I. K. N., \& Suadnyana, I. N. (2013). Pengaruh Strategi Pengorganisasian Pembelajaran Model Elaborasi Berbantuan Media Grafis terhadap Hasil Belajar IPS Kelas IV Sekolah Dasar. MIMBAR PGSD Undiksha, 1(1).

Pujani, N. M. (2018). Pelatihan Pembuatan Alat Peraga Ilmu Pengetahuan Bumi Antariksa bagi Kelompok Guru SMP dan SMA Lab. Undiksha Singaraja. International Journal of Community Service Learning, 2(1), 1-9. https://doi.org/http://dx.doi.org/10.23887/ijcsl.v2i1.13681. 
Rivalina, R. (2014). Kompetensi Teknologi Informasi dan Komunikasi Guru Technology (ICT) Dalam Peningkatan Kualitas Pembelajaran. Jurnal Teknodik, 18(2), 165-176.

Rizta, A., \& Antari, L. (2018). Pengembangan Tes Kemampuan Komunikasi Matematis Pada Materi Sistem Persamaan Linear Untuk Mahasiswa Calon Guru Matematika. AKSIOMA: Jurnal Program Studi Pendidikan Matematika, 7(2), 291-299. https://doi.org/10.24127/ajpm.v7i2.1525.

Saputri, V. A. C., \& Dewi, N. R. (2014). Pengembangan Alat Peraga Sederhana Eye Lens Tema Mata Kelas VIII untuk Menumbuhkan Keterampilan Peserta Didik. Jurnal Pendidikan IPA Indonesia, 3(2), 109115.

Sardinah, Tursinawati, \& Noviyanti, A. (2012). Relevansi Sikap Ilmiah Siswa Dengan Konsep Hakikat Sains Dalam Pelaksanaan Percobaan Pada Pembelajaran Ipa Di Sdn Kota Banda Aceh. Jurnal Pendidikan Serambi Ilmu, 13(2), 70-80.

Seruni, \& Hikmah, N. (2014). Pemberian Umpan Balik Dalam Meningkatkan Hasil Belajar dan Minat Belajar Mahasiswa. Formatif: Jurnal Ilmiah Pendidikan MIPA, 4(3), 227-236. https://doi.org/10.30998/formatif.v4i3.158.

Setiyani, R. (2010). Pemanfaatan Internet sebagai Sumber Belajar. Jurnal Pendidikan Ekonomi Dinamika Pendidikan, 5(2), 117-133. https://doi.org/10.15294/dp.v5i2.4921.

Sumiatun. (2013). Analisis Mutu Pembelajaran Praktikum Kebidanan sebagai Upaya Peningkatan Pencapaian Kompetensi Program Studi Diploma III Kebidanan STIKES Maharani Malang. Jurnal Kebijakan Dan Pengembangan Pendidikan, 1(1), 78-93.

Suryawati, E., \& Osman, K. (2018). Contextual Learning: Innovative Approach Towards The Development of Students' Scientific Attitude and Natural Science Performance. Eurasia Journal of Mathematics, Science and Technology Education, 14(1), 61-76. https://doi.org/10.12973/ejmste/79329.

Tias, I. W. U. (2017). Penerapan Model Penemuan Terbimbing untuk Meningkatkan Hasil Belajar IPA Siswa Sekolah Dasar. DWIJA CENDEKIA: Jurnal Riset Pedagogik, 1(1), 50-60. https://doi.org/10.20961/jdc.v1i1.13060.

Tobing, S. M. (2019). Pemanfaatan Internet sebagai Media Informasi Dalam Kegiatan Belajar Mengajar Pada Mata Kuliah Pendidikan Pancasila. JURNAL PEKAN: Jurnal Pendidikan Kewarganegaraan, $4(1), 64-73$.

Wulandari, F. E. (2016). Pengaruh Model Pembelajaran Berbasis Proyek untuk Melatihkan Keterampilan Proses Mahasiswa. PEDAGOGIA: Jurnal Pendidikan, 5(2), 247-254. https://doi.org/10.21070/pedagogia.v5i2.257.

Wulandari, Y. I., Sunarto, \& Totalia, S. A. (2015). Implementasi Model Discovery Learning dengan Pendekatan Saintifik untuk Meningkatkan Kemampuan Berfikir Kritis dan Hasil Belajar Siswa Mata Pelajaran Ekonomi Kelas XI IIs I SMA Negeri 6 Surakarta Tahun Pelajaran 2014/2015. BISE: Jurnal Pendidikan Bisnis Dan Ekonomi, 1(2), 1-21.

Yuliyanti, N. (2016). Pengaruh Model Inkuiri Terbimbing Berbasis Lingkungan terhadap Kemampuan Pemahaman Konsep dan Karakter. Cakrawala Pendas, 2(2), 1-10. 